\title{
Income Distribution in the World: Yesterday, Today, Tomorrow
}

\author{
Betül İnam*
}

Bursa Uludag University, Faculty of Economics and Administrative Sciences, Department of Public Finance, Bursa- Turkey

\author{
DOI: $10.36348 /$ SJEF.2019.v03i10.003 $\quad$ | Received: 05.10.2019| Accepted: 12.10.2019| Published: 20.10 .2019 \\ *Corresponding author: Betül İnam
}

\section{Abstract}

Income inequality is one of the most significant impediments to the development and welfare of countries. Increased income inequality can cause to social conflict and affects social coherence negatively. Such economies become unstable and unsustainable in the long run. An inequitable distribution of income adversely affects the economic development in developing countries and inhibits the emergence of economic and political institutions that could support growth and investment. Events, which have a profound effect on societies, such as wars, revolutions, technological development and great economic crisis, might result with the elimination of income inequality in a region or country in a relatively short time. However, without such profound events, the tradition of income inequality could take centuries of efforts to achieve certain change. The present study, therefore, discusses the history of income inequality in the world, the current situation and future forecasts and presents relevant findings and suggestions.

Keywords: Income distribution, income inequality, Gini coefficient, percentage share.

Copyright @ 2019: This is an open-access article distributed under the terms of the Creative Commons Attribution license which permits unrestricted use, distribution, and reproduction in any medium for non-commercial use (NonCommercial, or CC-BY-NC) provided the original author and source are credited.

\section{INTRODUCTION}

Equality and justice are of the most discussed and most challenging concepts to define throughout the history. The concept of justice was considered as a subject of philosophy for years. In nineteenth century, justice became a focus of interest in different disciplines, such as law, sociology and economics [1].

Justice refers to an equal distribution of income in an economy, between individuals, regions, sectors or production elements, in terms of income distribution. The concept of income distribution is closely associated with social justice and equality concepts. Knowing how income is distributed is significant for the improvement of the capital and social structure, when making social and economic decisions [2]. Income distribution explains the relationships between social and economic institutions, changes in income gap between the enfranchised and disenfranchised in time, the effects of income inequalities on improvements in capital and growth, and the distribution of resources [3].

It is possible to analyze income distribution through four different types, personal, functional, sectoral and geographical. Such types of income distribution complement each other. However, international comparisons most commonly use personal income distribution. An extensive range of instruments are used in measuring income inequalities. Currently, the two most commonly used tools are the Gini Coefficient and Percentage Share. The main objective in choosing these instruments is their suitability for international comparisons. The development level and prosperity of a country is related with the fair distribution of its national income. Income distribution is a concept referred to with prosperity, social justice and social peace. Increased income inequality between individuals or social segments lead to social conflicts, disruption of social coherence and economic instability. Such results constitute one of the most significant impediments to economic development and growth [4]. Given that high income inequality is linked with discrimination and protection of privileges, it might lead individuals to detach themselves from productive economic activities [5]. Such economies suffer instability and unsustainability in the long run. Latin American countries, which are among the countries that experience world's highest income inequalities, encountered internal turmoil, high crime rates and economic and social instability for several years [6]. An 
unfair distribution of income adversely affects growth in developing countries and inhibits the emergence of economic and political institutions that could support investment. Income inequality hampers equality in opportunities and causes insufficient support for social public investments for the disenfranchised and middle classes. Such impact does not affect only the poorest $10 \%$ in the society, yet, could extent up to the poorest $40 \%$ in income distribution [7].

Although income inequality existed for the last two centuries, it increased dramatically due to the accelerating globalization since the 1980s. Aligned with the opportunities offered via globalization, the involved risks also cause income inequalities. Currently, the difference between the rich and poor continues to increase, despite the increasing wealth throughout the world. While the wealthiest $10 \%$ receives $40 \%$ of the global income, the share of the poorest $10 \%$ in the global income is between 2 and 7\%. Increased income inequality threatens social cohesion, slows down economic growth and invalidates the policies that target to eliminate poverty [8]. Recent studies indicated that income inequality was not only a problem for the poor countries. Several developed countries currently have an income distribution that is further unfair when compared to the past. The aim of the present study is to examine the dimensions of income inequality in the world through the history and interpret the findings.

\section{INCOME DISTRIBUTION IN THE WORLD}

It is not possible to state that there exists a consistent trend of the imbalances in income distribution in the world. The history of inequality is shaped through strong social changes as well as economic events. Socio-economic inequalities, differences in the income and wealth between different groups in the society continue to be the cause or effect of the experienced changes. Global inequality continued to escalate during the period that was marked with industrial revolution, which provided a rapid growth in European countries, America and Canada, to the midtwentieth century [9]. Currently, the difference between the living standards of individuals in wealthy and poor countries is unpredictable, when compared to the period before the $1800 \mathrm{~s}$. While the income gap between the societies with the best and the worst economic conditions in the pre-industrial period was 3 to 4 times, this difference increased up to 40 times in the present day [10]. The analysis of the causes of global income inequality yields various factors such as technological changes, increased importance of financing, structural changes in labor markets, globalization, and increased domestic inequalities [11]. Particularly, factors such as globalization, neo-liberal policies and technological development, which gained momentum since the 1980s, changed the social and economic balances [12]. Currently, fair income distribution is no longer only the problem of poor countries. The income distribution of the developed countries in the world substantially changed when compared to the pre-1980 period.

Table 1 presents the Gini Coefficients of the selected countries from various geographies of the world throughout the history.

Table-1: Gini Coefficients of the Selected Countries (1820-2000)

\begin{tabular}{|l|l|l|l|l|l|l|l|l|l|}
\hline Year & England & France & Italy & Russia & USA & Brazil & Turkey & Chine & Japan \\
\hline $\mathbf{1 8 2 0}$ & 0,59 & 0,59 & 0,54 & 0,58 & 0,57 & 0,47 & 0,58 & 0,45 & 0,53 \\
\hline $\mathbf{1 8 5 0}$ & 0,43 & 0,54 & 0,51 & 0,54 & 0,44 & 0,37 & 0,37 & 0,33 & 0,46 \\
\hline $\mathbf{1 8 7 0}$ & 0,49 & 0,58 & 0,51 & 0,50 & 0,51 & 0,39 & 0,56 & 0,41 & 0,46 \\
\hline $\mathbf{1 8 9 0}$ & 0,37 & 0,48 & 0,46 & 0,38 & 0,46 & 0,36 &.. & 0,31 & 0,47 \\
\hline $\mathbf{1 9 1 0}$ & 0,42 & 0,55 & 0,49 & 0,40 & 0,51 & 0,38 &.. & 0,39 & 0,52 \\
\hline $\mathbf{1 9 3 0}$ & 0,43 & 0,62 & 0,51 & 0,43 & 0,54 & 0,60 & 0,54 & 0,44 & 0,52 \\
\hline $\mathbf{1 9 5 0}$ & 0,30 & 0,58 & 0,43 & 0,36 & 0,39 & 0,49 & 0,49 & 0,32 & 0,36 \\
\hline $\mathbf{1 9 6 0}$ & 0,29 & 0,52 & 0,44 & 0,28 & 0,38 & 0,55 & 0,55 & 0,31 & 0,38 \\
\hline $\mathbf{1 9 7 0}$ & 0,29 & 0,45 & 0,39 & 0,23 & 0,36 & 0,58 & 0,52 & 0,28 & 0,35 \\
\hline $\mathbf{1 9 8 0}$ & 0,34 & 0,35 & 0,39 & 0,25 & 0,37 & 0,57 & 0,50 & 0,30 & 0,37 \\
\hline $\mathbf{1 9 9 0}$ & 0,39 & 0,37 & 0,33 & 0,26 & 0,40 & 0,59 & 0,44 & 0,34 & 0,36 \\
\hline $\mathbf{2 0 0 0}$ & 0,40 & 0,37 & 0,37 & 0,40 & 0,44 & 0,61 & 0,46 & 0,34 & 0,33 \\
\hline
\end{tabular}

Resource: OECD, “How was life? Global Well-Being Since 1820”, p. 206

\section{Information}

The Gini Coefficient measures the inequality level with a single value between 0 and 1 . The coefficient close to 1 indicates that the inequality increases and close to 0 indicates that the inequality decreases. 
In general, the Gini coefficients presented in Table 1 for the $19^{\text {th }}$ century are estimations obtained from the information from indirect sources[13]. However, it is possible to consider these values as an important data set in order to evaluate income inequality through a global and historical perspective. In 1820 s, income inequality is high in most countries. Europe, America, Turkey, Russia, Japan had a coefficient value larger than 0.50. Only Brazil, Argentina and China achieved coefficient values lower than 0.50 . The inequality in income distribution began to improve at a global level after 1820 s, escalated once more between the two world wars of the $20^{\text {th }}$ century and decreased relatively during the period marked between the World War II and 1980s. Such decrease in income inequality during this period was possibly due to the chaos caused by wars and economic and political shocks triggered by the wars. Bankruptcy due to Great Depression in the 1930s and the public policies put in action caused a significant decrease in the capital/income ratio during the period between 1914 and 1945 and in the share of capital revenues from the national income. The shocks that capital was exposed to during the period between 1914 and 1945 led to a decrease in the share of the upper tenth percentile, thus to a decrease in income inequality [14]. In most developed countries, a declining course was prevalent between 1950 and 1980 in income inequality. It would not be inaccurate to state that the predominance of welfare state and development policies, especially in developed countries, and the ending of the world wars had a significant effect on the regression of income inequalities during this period. However, such trend was reversed due to the neoliberal policies that emerged at $1980 \mathrm{~s}$, the decrease in state interventions and the acceleration of globalization. The Gini coefficient in the UK was 0.34 in 1980, yet, increased to 0.40 in 2000 s. The comparison between the Gini Coefficients of Japan and the United States yields a remarkable difference. Studies associated such difference between these two countries with the distinctions in education, changes in labor markets and with the presence of a large middle class in Japan [15]. The Gini Coefficient in Russia, during the period between 1980 and 1990 was between 0.25 and 0.26 and increased to 0.40 in 2000. Income distribution was dramatically disrupted due to the disintegration of the Soviet Union in 1990. A new oligarchy was created in Russia due to the rapid transition from planned to free market economy, implemented reforms and the effect of privatization programs. Majority of the society's savings depreciated due to excessive inflation between 1990 and 1999. Late or unpaid salaries devastatingly affected the living standards and created a widening gap between the rich and the poor [16]. On the other hand, there existed a significant increase in income inequality in China, the United States and Latin America. The countries that exhibited a decline in income inequality from 1980 to the present day were Turkey and Japan. Turkey's Gini Coefficient by 2015 was calculated as 0.40 . However, such value is a clear indication that fair distribution of national income could not be achieved. Table 2 presents the regional averages of income inequality between 1820 and 2000.

Table-2: Regional Averages of Income Inequality (1820-2000)

\begin{tabular}{|c|c|c|c|c|c|c|c|c|}
\hline Year & $\begin{array}{l}\text { Western } \\
\text { Europe }\end{array}$ & $\begin{array}{l}\text { Eastern } \\
\text { Europe }\end{array}$ & $\begin{array}{l}\text { Western } \\
\text { Offshoots }\end{array}$ & $\begin{array}{c}\begin{array}{c}\text { Latin } \\
\text { America }\end{array} \\
\text { Caribbean }\end{array}$ & $\begin{array}{l}\text { East } \\
\text { Asia }\end{array}$ & $\begin{array}{c}\text { South and } \\
\text { South } \\
\text { East Asia }\end{array}$ & $\begin{array}{c}\text { Middle } \\
\text { East and } \\
\text { North } \\
\text { Africa }\end{array}$ & $\begin{array}{c}\text { Sub } \\
\text { Saharan } \\
\text { Africa }\end{array}$ \\
\hline 1820 & 0,54 & 0,51 & 0,51 & 0,45 & 0,45 & 0,35 & - & 0,53 \\
\hline 1850 & 0,45 & 0,49 & 0,42 & 0,37 & 0,34 & 0,38 & 0,46 & 0,46 \\
\hline 1870 & 0,50 & 0,48 & 0,51 & 0,48 & 0,41 & 0,42 & 0,52 & 0,50 \\
\hline 1890 & 0,41 & 0,36 & 0,45 & 0,41 & 0,32 & 0,34 & 0,35 & 0,36 \\
\hline 1910 & 0,46 & 0,39 & 0,50 & 0,45 & 0,40 & 0,35 & 0,40 & 0,42 \\
\hline 1929 & 0,48 & 0,40 & 0,52 & 0,55 & 0,44 & 0,36 & 0,48 & 0,48 \\
\hline 1950 & 0,42 & 0,35 & 0,39 & 0,47 & 0,33 & 0,39 & 0,43 & 0,43 \\
\hline 1960 & 0,40 & 0,30 & 0,37 & 0,54 & 0,32 & 0,39 & 0,49 & 0,53 \\
\hline 1970 & 0,38 & 0,26 & 0,36 & 0,53 & 0,29 & 0,40 & 0,47 & 0,49 \\
\hline 1980 & 0,36 & 0,27 & 0,37 & 0,52 & 0,31 & 0,35 & 0,47 & 0,46 \\
\hline 1990 & 0,38 & 0,27 & 0,39 & 0,52 & 0,34 & 0,41 & 0,46 & 0,47 \\
\hline 2000 & 0,40 & 0,36 & 0,44 & 0,54 & 0,43 & 0,48 & 0,46 & 0,49 \\
\hline
\end{tabular}

Resource: OECD, "How was life? Global Well-Being Since 1820", p. 210

Information: Western Offshoots includes the US, Canada and Australia 
Table 2 indicates that Latin America and the Caribbean were the regions with the highest inequality rates in the $20^{\text {th }}$ century. Although this particular region had the lowest level of inequality along with the Asian countries in the $19^{\text {th }}$ century, this trend was reversed in the following periods. It is estimated that rapid economic growth caused domestic inequalities in both geographies [13]. It is possible to notice that inequalities in the Eastern Europe were quite low compared to other regions, during the period between 1950 and 1990. However, it is evident that the disintegration of the Soviet Union in 1990 resulted with a rapid expansion of the inequalities. On the other hand, inequalities in income distribution rapidly declined in the Western Europe, from 1820s to 1980s. A slight increase was observed after 1980s. Although a similar trend with Western Europe was observed in the US, Canada and Australia, which are called western offshoots, until the 1980 s, there was a rapid increase in income inequalities after 1990. Especially in the US, inequality has been rapidly increasing since 1980 . While the share of the upper tenth percentile in the national income was 30 to $35 \%$ in the 1970 s, this share increased to 40 to $45 \%$ during the period between 2000 and 2010. Given the continued increase of this rate, the share of the upper tenth percentile might reach to $60 \%$ in 2030. The reasons for this increase were explained through the record increases in wage inequality and the emergence of extremely high premiums, especially among the executive staffs of the large companies. Furthermore, the high inequality in capital incomes accounts for one third of the increase in income inequalities in the US. A further clarification to the increasing inequality resides in the capital revenues that are declared lower than other revenues due to tax avoidance or evasion. Additionally, the share of the upper tenth percentile in the national income reached to a record level for two times, the first was in 1928 and the second in 2007. There is no doubt that the increase in inequalities rendered the US financial system fragile [14]. Although there exists a time-dependent decline in income inequalities in the Middle East, North Africa and Sub-Saharan Africa, it is possible to state that high income inequalities were commonly dominant throughout the history.

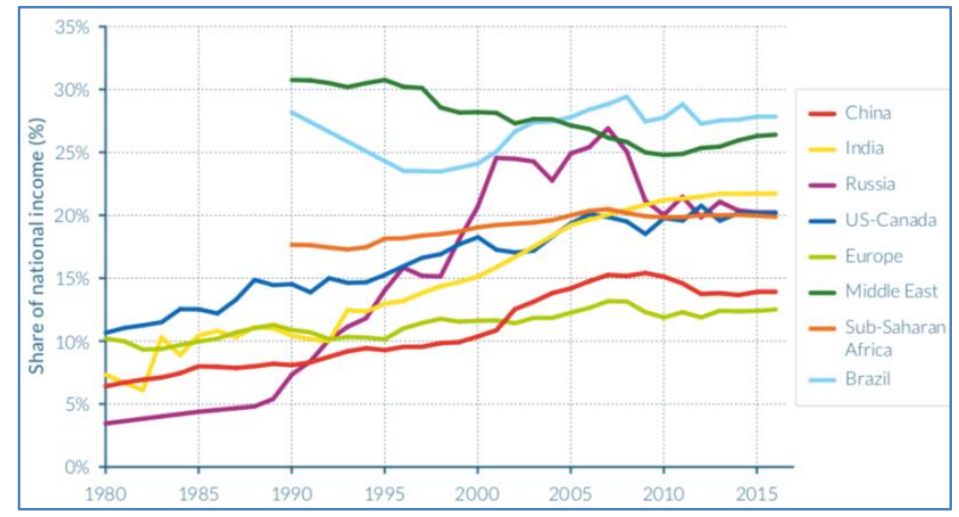

Chart-1: Top 1\% income shares across the world (1980-2016)

Resource: World Inequality Report 2018

Chart 1 indicates that the share of the upper first percentile in Russia, India and North America in the national income rapidly increased since 1980 . While the share of the upper first percentile in national income in Russia was below $5 \%$, it increased to over $20 \%$ by the year 2015. The highest level in shares was observed during the period between 2005 and 2010, which corresponds to the Global Crisis. Although the share of the upper first percentile in North America and Europe were similar in 1980, the share in North America became much more unequal compared to that of Europe by 2015 . The share of the wealthiest $1 \%$ in both regions in the national income were approximately $10 \%$ in
1980, and the share did not change drastically in Europe by 2015 , yet the share of the upper first percentile in North America increased almost twice. The regions with the highest share of the upper first percentile in national income are the Middle East and Brazil. Although the share of the wealthiest $1 \%$ in national income was around $30 \%$ in the 1990 s, these regions currently exhibit a relative decline. However, Middle East and Latin America continue to be the regions with the highest income inequalities in the world. Chart 2 indicates the trend for the fiftieth percentile that received the lowest share of the national income worldwide between 1980 and 2016 . 


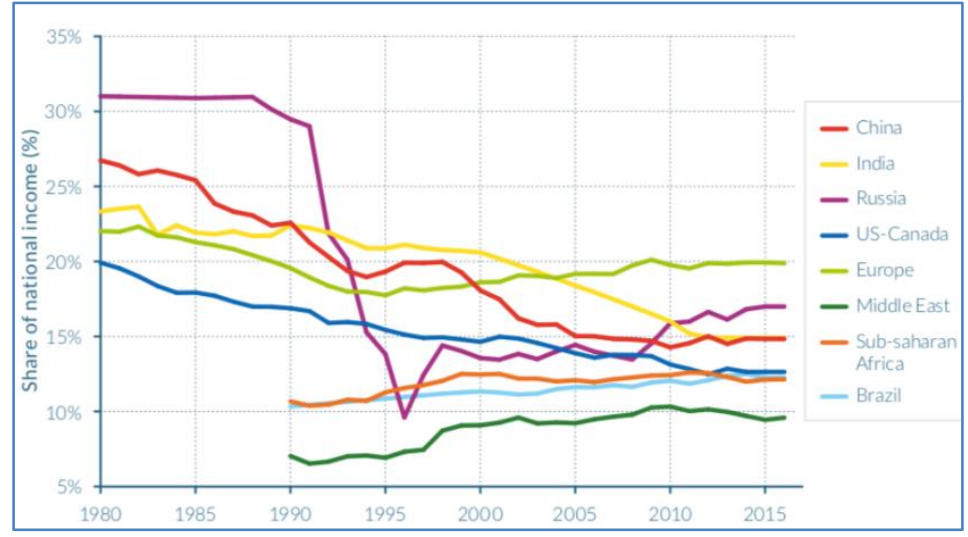

Chart-2: Bottom 50\% income share across the world (1980-2016)

Resource: World Inequality Report 2018

Chart 2 represents that the poorest $50 \%$ in Russia received the highest share of the national income by $30 \%$ in 1980 . The process initiated due to the disintegration of the Soviet Union, the share of the poorest $50 \%$ declined rapidly and currently reached to $15 \%$. The share of the poorest $50 \%$ in India and China exhibited a rapid decline, similar to Russia, in the last thirty years. Such trend also applies to North America. On the contrary, the share of the poorest $50 \%$ from national income tends to increase in the Middle East and Brazil. Yet, these regions include countries where the poorest $50 \%$ receive the lowest share of the national income. The share of the poorest $50 \%$ decreased also in Europe, similar to other regions, in the last 30 years. However, the poorest $50 \%$ in the European countries still have the highest share in national income. The effect of the social welfare state practices employed in the European countries for a fair in income distribution can clearly be observed based on these results.

Chart 3 presents the trends for the global wealthiest $1 \%$ and global poorest $50 \%$ between 1980 and 2016.

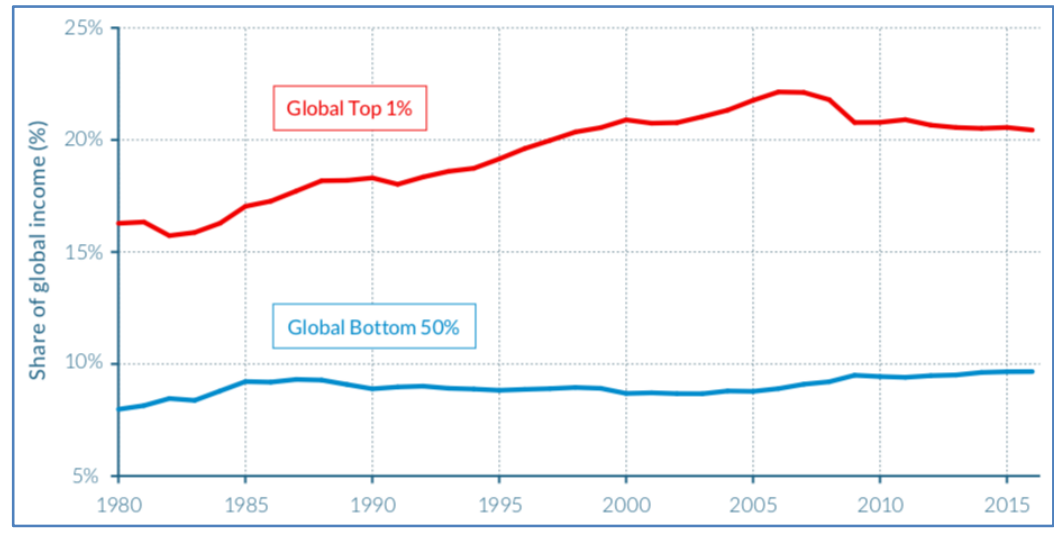

Chart-3: The global top 1\% and the global bottom 50\% (1980-2016)

Resource: World Inequality Report 2018

The share of the wealthiest $1 \%$ in the global income was increasing rapidly since 1980 . The share which was $16 \%$ in 1980 increased almost to $20 \%$ in 2015. The share of the poorest $50 \%$ in the global income was stagnant and did not exceed the 9 to $10 \%$ range in the last 30 years. Such developments at the global level could stem from various reasons. It could be argued that the recent increases in domestic inequalities triggered global inequalities. Differences between developed and developing countries, negative effects of globalization, wars and economic crises are among the most important factors that affect income inequalities.

The report prepared by the British aid agency OXFAM indicated that the wealth of the richest 388 people was equal to the wealth of 3.6 billion people in 2010, yet the figures in 2015 showed that the wealth of the richest 62 people equaled to the wealth of same number of people. The average annual income of the 
world's poorest $10 \%$ increased by less than $\$ 3$ on average per year, in the last 25 years [17]. The future of global income inequality is expected to be shaped through the rapid growth in developing countries and the inequality rates within these countries. However, it is challenging to predict which of these influences might be more dominant or whether high income inequalities are sustainable. Nevertheless, global inequalities are expected to increase due to the continued increase in domestic inequalities [18]. Income inequalities are largely the result of state policies that shape technology, market and social dynamics. Yet, inequality is not inevitable. Policy shifts could lead to a more efficient and fair income distribution. However, it is challenging to create a shift in the political processes that shape policies. Any misconduct at the macro level might become a major factor for inequality [6]. If all countries in the world experience a rapid rise in income inequality like the US since 1980 , the global wealthiest $1 \%$ is expected to receive a $28 \%$ share of the global income in 2050 and the global poorest $50 \%$ will receive a $6 \%$ share. In the event of an income inequality with a slowly increasing trend as in the European countries, the estimations for 2050 indicate that the share of the global richest $1 \%$ will receive will decrease to $19 \%$ of the global income and the share of the global poorest $50 \%$ will increase to $13 \%$ [18].

\section{CONCLUSION}

Income inequality, in other words, the inequality in the distribution of the income, is not an economic event that has the potential to change over a short time. The change in income inequality in a region or country in a relatively short time is only probable due to significant social events such as war, revolution, technological development and major economic crisis. Otherwise, changing the tradition of income inequality in a state could require extensive efforts that last for centuries. The findings of conducted studies confirm this hypothesis. However, income inequalities are not inevitable. Policy change could lead to a more productive and more egalitarian society. Indeed, it is probable to reorganize income distribution through using fiscal policy instruments. Significant examples for such practices are prevalent in European countries. Effective and efficient use of public expenditures with an accent on social quality, the weight of direct taxes in the tax system, the development of democratic institutions, and the emphasis on social policy practices are vital in eliminating income inequalities. It is also considered that the future of global income inequality will be influenced by the rapid growth and domestic inequalities in developing countries. However, there is still certain controversy as to which of these would be more effective and whether growth and income inequalities are sustainable. Despite the optimistic assumptions on the growth in developing countries, the inadequacy in democratic institutions and in social policy practices indicates that income inequalities would continue to increase in the future.

\section{ACKNOWLEDGEMENT}

This study is a part of the author's $\mathrm{PhD}$ thesis.

\section{REFERENCES}

1. Topakkaya, A. (2008). Adalet Kavramı Bağlamında Aristoteles-Platon Karşılaştırması, Felsefe ve Sosyal Bilimler Dergisi, 6, 27-46.

2. Pehlivan, M. S. (2009). Gelir Dağılımı Eşitsizliğine Devletin Müdahale Araçları: Sosyal Yardımlaşma ve Dayanışmayı Teşvik Fonu Örneği (Sosyal Yardım Uzmanlık Tezi), Ankara, Başbakanlık Sosyal Yardımlaşma ve Dayanışma Genel Müdürlüğü Yayını.

3. Han, E. (2010). Gelir Dağılımı Adaletine Yönelik Ekonomik Politikalar, Ankara, Türkiye Kamu-Sen Ar-Ge Merkezi Yayın No: 36.

4. Öztürk, N. (2009). İktisatta Bölüşüm, Ankara, Palme Yayıncilik.

5. Derviş, K. (2015). Küreselleşme, Büyüme ve Gelir Dağılımı, Dış İşleri Bakanlığı, http://www.mfa.gov.tr/data/Kutuphane/yayinlar/Ek onomikSorunlarDergisi/sayi27/kuresellesme_buyu me_gelir_dagilimi.pdf, Access Date: 12.12.2015

6. Stiglitz, J. E. (2015). Price of Inequality. How today's Divided Society Endangers Our Future (Eşitsizliğin Bedeli Bugünün Bölünmüş Toplumu Geleceğimizi Nasıl Tehlikeye Atıyor?), İstanbul, İletişim Yayınları.

7. OECD. (2015). Inequality and Inclusive Growth Policy Tools to Achieve Balanced Growth in G20 Economies, Antalya, OECD Publishing.

8. Eurostat. (2017). Sustainable Development in the European Union 2017, Luxembourg, European Union Publishing.

9. Milanovic, B. (2013). Global Income Inequality in Numbers: in History and Now, Global Policy, 4(2), 198-208.

10. Clark, G. (2013). Fukaralığa Veda Dünyanın Kısa İktisadi Tarihi, İstanbul, Bilgi Üniversitesi Yayınlar1.

11. Qureshi, Z. (2017). Trends in income inequality: global, inter-country and within countries, https://www.brookings.edu/wpcontent/uploads/2017/12/global-inequality.pdf, Access date: 31.01 .2018

12. Danışoğlu, A. (2004). Küreselleşmenin gelir eşitsizliği ve yoksulluk üzerindeki etkileri, İstanbul Ticaret Üniversitesi Dergisi, 5, 215-239. 
13. OECD. (2014). How was life? Global Well-Being since 1820, Paris, OECD Publishing.

14. Piketty, T. (2014). Capital in Twenty-First Century (Yirmi Birinci Yüzyılda KAPITAL), İstanbul, Türkiye İş Bankası Kültür Yayınları.

15. Aizawa, T., Dekle, R., Helble, M. (2017). Sources of Income Inequality: A comparison of Japan and the United States, ADBI Working Paper Series No: 663, Tokyo.

16. Russel, M. (2018). Sosyoeconomic inequality in Russia,
http://www.europarl.europa.eu/RegData/etudes/AT AG/2018/620225/EPRS_ATA(2018)620225_EN.p df, Access Date: 12.10.2018.

17. Oxfam International. (2016). 210 Oxfam Briefing Paper, Oxford, Oxfam GB.

18. Alvaredo, F., Chancel, L., Piketty, T., Saez, E., Zucman, G. (2018). World Inequality Report 2018, https://wir2018.wid.world/files/download/wir2018full-report-english.pdf, Access Date: 16.03.2018. 